\title{
MENINGKATKAN HASIL BELAJAR PADA KOMPETENSI MEMBACA DENGAN MODEL THINK PAIR AND SHARE PADA SISWA SMP NEGERI 117 JAKARTA
}

\author{
MARGA PURNAMA \\ SMP Negeri 117 DKI Jakarta \\ e-mail : margapurnama87@gmail.com
}

\begin{abstract}
ABSTRAK
Penelitian ini dibuat karena melihat kenyataan di lapangan kurangnya minat peserta didik terhadap pelajaran bahasa Indonesia khususnya membaca. Untuk itu peneliti menggunakan model think pair and share. Sampel pada penelitian ini adalah siswa kelas VII-7 SMP Negeri 117 Jakarta Timur yang berjumlah 35 orang. Tahapan siklus I dan siklus II masing-masing tiga kali pertemuan. Rata-rata nilai pada siklus I 74.85 namun ada 9 siswa yang nilainya di bawah KKM sehingga ketuntasan belajar masih $73.52 \%$. Sedangkan pada siklus II rata-rata nilai 79.71 terjadi peningkatan nilai 4.86 dan ketuntasan belajar mengalami peningkatan menjadi $80 \%$,ada peningkatan $6.48 \%$. Sementara aktivitas belajar siswa juga mengalami peningkatan pada siklus I $72.54 \%$ menjadi $79.98 \%$ pada siklus II sehingga terjadi peningkatan $7.44 \%$. Hal ini sesuai dengan indikator keberhasilan lebih dari sama dengan 75\%. Dari seluruh analisis data.dapat disimpulkan bahwa model pembelajaran think pair and share dapat meningkatkan hasil belajar bahasa Indonesia.
\end{abstract}

Kata Kunci: hasil belajar, kompetensi membaca, model think and share

PENDAHULUAN

Salah satu masala yang dihadapi dunia pendidikan adalah lemahnya proses pembelajaran. Dalam proses pembelajaran, anak kurang didorong untuk mengembangkan kemampuan berpikir. Proses pembelajaran cenderung diarahkan kemampuan anak untuk menghafal dan dipaksa untuk mengingat dan menimbun berbagai informasi tanpa dituntut untuk memahami informasi yang diingatnya untuk menghubungkannya dengan kehidupan sehari-hari. (Sanjaya, 2011)

Bahasa merupakan salah satu alat komunikasi antar manusia. Melalui bahasa, manusia dapat saling berhubungan, saling berbagi pengalaman, saling belajar dari yang lain.dan meningkatkan kemampuan intelektual. Manusia sebagai makhluk sosial ingin selalu berkomunikasi dengan orang lain untuk menyampaikan ide-ide, gagasan-gagasan kepada orang lain untuk memenuhi kebutuhan hidupnya.nApabila seseorang ingin menguasai suatu bahasa maka harus memiliki penguasaan kosakata, tatabahasa, ejaan, dSAiksi dari bahasa yang ingin dikuasainya. Hal ini dapat diperoleh melalui kegiatan membaca. Melalui membaca seseorang mendapat pengetahuan yang belum diketahuinya dan dapat "mengalami" dengan cara alamiah sehingga pengetahuan yang dibacanya tersebut berguna bagi dirinya dan dekat dengan kebutuhan pribadinya.

Dalam pembelajaran bahasa mencakup empat aspek, antara lain mendengarkan, berbicara, membaca, dan menulis. Keempat aspek tersebut saling berkaitan dan akan berpengaruh terhadap kemampuan siswa dalam berbahasa. Membaca sebagai salah satu bagian dari keterampilan berbahasa yang harus dimiliki agar siswa dapat memahami konsep secara tepat dan kreatif untuk berbagai tujuan, meningkatkan kemampuan intelektual, dan kemampuan berbahasa. (Priyatni, 2014).

Kurikulum bahasa Indonesia terus disempurnakan dengan tujuan dapat meningkatkan mutu pendidikan bahasa Indonesia sehingga mampu menjawab segala permasalahan yang dihadapi siswa. Namun pada kenyataaannya keinginan siswa untuk membaca masih kurang. Hal ini terlihat dari kemampuan siswa memahami soal yang berupa pemahaman isi bacaan perolehan 
nilai mereka masih dibawah KKM. Salah satu penyebab rendahnya kemampuan membaca karena model pembelajaran yang kurang tepat digunakan pada saat pembelajaran berlangsung, sehingga berpengaruh terhadap keberhasilan siswa dalam memahami sebuah bacaan dari segi isi, gagasan, dan keterampilan untuk menceritakan kembali bacaan.

Setelah siswa mempelajari materi yang diberikan guru selama kegiatan belajar, maka untuk mengukur sejauhmana kemampuan siswa tersebut dilakukanlah tes sebagai hasil belajar dari siswa. Menurut Dimyati dan Mudjiono (2013: 200) bahwa "Hasil belajar merupakan proses untuk menentukan nilai belajar siswa melalui kegiatan penilaian dan pengukuran hasil belajar". Adapun hasil belajar merupakan manisfestasi dan symbol numerik yang diberikan sebagai tanda dan apresiasi terhadap kemampuan belajar siswa. Menurut Djamarah (2000: 45), hasil adalah prestasi dari suatu kegiatan yang telah dikerjakan, diciptakan, baik secara individu maupun kelompok. Hasil tidak akan pernah dihasilkan selama orang tidak melakukan sesuatu. Untuk menghasilkan sebuah prestasi dibutuhkan perjuangan dan pengorbanan yang sangat besar. Hanya dengan keuletan, sungguh-sungguh, kemauan yang tinggi dan rasa optimisme dirilah yang mampu untuk mancapainya. Keberhasilan suatu proses pembelajaran dapat diukur dari daya serap siswa terhadap bahan ajar yang terintegrasi pada prestasi belajar yang dicapai oleh siswa. Semakin tinggi hasil belajar siswa menunjukan semakin tinggi tingkat keberhasilan suatu proses pembelajaran. Demikian pula sebaliknya, semakin rendah hasil belajar siswa maka tingkat keberhasilan proses pembelajaran juga rendah.

Sementara itu, Arikunto (2006:133) mengatakan bahwa hasil belajar adalah hasil akhir setelah mengalami proses belajar, perubahan itu tampak dalam perbuatan yang dapat diamati.dan dapat diukur". Perubahan yang dimaksud dalam hasil belajar tidak hanya pembahan pengetahuan, tetapi juga meliputi perubahan kecakapan, sikap, pengertian, dan penghargaan diri pada individu tersebut. Adapun penjelasan yang lain dikatakan bahwa hasil belajar adalah kemampuan yang diperoleh anak setelah melalui kegiatan belajar (Suprijono, 2011: 106). Sedangkan dalam Kunandar (2013: 62) menjelaskan bahwa hasil belajar merupakan kompetensi atau kemampuan tertentu baik kognitif, afektif maupun spikomotorik yang dicapai oleh peserta didik setelah mengikuti proses belajar mengajar. Jadi, hasil belajar adalah kemampuan-kemampuan yang dimiliki siswa setelah ia menerima pengalaman belajar. Individu yang belajar akan memperoleh hasil dari apa yang telah dipelajari selama proses belajar itu. Dengan begitu siswa akan bertambah pengetahuannya melalui pengalaman belajar yang diperolehnya.

Beberapa permasalahan yang muncul tersebut memerlukan adanya tindakan yang dapat meningkatkan aktivitas dan hasil belajar Bahasa Indonesia yaitu dengan menggunakan model pembelajaran kooperatif. Model pembelajaran kooperatif (Cooperative Learning) merupakan salah satu model pembelajaran yang mendukung pembelajaran kontekstual. Sistem pengajaran Cooperative Learning dapat didefinisikan sebagai sistem kerja/belajar kelompok yang terstruktur. Roger dan David dalam Lie (2005:31) mengatakan bahwa tidak semua kerja kelompok bisa dianggap cooperative learning. Untuk mencapai hasil yang maksimal, lima unsur model pembelajaran gotong royong harus diterapkan, lima unsur tersebut adalah saling ketergantungan positif, tanggung jawab perseorangan, tatap muka, komunikasi antar anggota, dan evaluasi proses kelompok.

Adapun salah satu tipe pembelajaran berbasis model pembelajaran kooperatif adalah model pembelajaran tipe Think Pair Share (TPS). Model pembelajaran ini diharapkan dapat melibatkan siswa secara aktif dalam pembelajaran bahasa Indonesia dengan berpikir secara individu kemudian berdiskusi berpasangan dengan teman sebangkunya. Melalui model ini siswa dapat melatih kemampuan berpikir, membuat siswa bertanggung jawab, bekerjasama, berpendapat, memahami materi secara individu maupun melalui bantuan orang lain. 
Definisi dari model pembelajaran kooperatif tipe Think Pair and Share (TPS) dikemukakan oleh Lie (2005: 57) menyatakan bahwa, Think-Pairs-Share adalah pembelajaran yang memberi siswa kesempatan untuk bekerja sendiri dan bekerjasama dengan orang lain. Sedangkan Mulyatiningsih (2011: 233) juga mengemukakan bahwa: TPS merupakan metode pembelajaran yang dilakukan dengan cara sharing pendapat antar siswa. Metode ini dapat digunakan sebagai umpan balik materi yang diajarkan guru. Pada awal pembelajaran, guru menyampaikan materi pelajaran seperti biasa. Guru kemudian menyuruh dua orang peserta didik untuk duduk berpasangan dan saling berdiskusi membahas materi yang disampaikan oleh guru. Pasangan peserta didik saling mengkoreksi kesalahan masing-masing dan menjelaskan hasil diskusinya di kelas. Guru menambah materi yang belum dikuasai peserta didik berdasarkan penyajian hasil diskusi. Strategi TPS atau berpikir berpasangan berbagi dikemukakan oleh Trianto (2011: 61) bahwa TPS adalah merupakan jenis pembelajaran kooperatif yang dirancang untuk mempengaruhi pola interaksi siswa. Strategi think-pair-share ini berkembang dari penelitian belajar kooperatif dan waktu tunggu.

Model pembelajaran kooperatif tipe Think Pair Share ini dikembangkan pertama kali oleh Frank Lyman dari University of Maryland. Siswa diberikan banyak kesempatan untuk menyelesaikan permasalahan secara mandiri sebelum berdiskusi dengan pasangannya (tahap think). Setelah itu masing-masing siswa dapat berdiskusi atau berbagi pendapat dengan pasangannya (tahap pair). Tahapan selanjutnya yaitu tahap share, perwakilan dari kelompok dapat menjelaskan jawaban mereka di depan kelas, sedangkan kelompok lain dapat menanggapi dan bertanya kepada kelompok yang mempresentasikan jawabannya (Sirajuddin dan Samparadja, 2015:84). Dengan menggunakan model pembelajaran ini, diharapkan dapat meningkatkan hasil belajar Bahasa Indonesia siswa karena sudah dibuktikan dengan adanya penelitian terdahulu yang menunjukkan bahwa model pembelajaran ini dapat meningkatkan hasil belajar siswa.

Berdasarkan pengamatan awal yang dilakukan, selama proses pembelajaran masih banyak siswa bermasalah dengan hasil belajar yang kurang memuaskan. Pendapat tersebut dapat dibuktikan dari rata-rata nilai UAS (Ulangan Akhir Semester) kelas VII SMP Negeri 117 Jakarta yang masih terggolong rendah dan masih dibawah standar kelulusan.

Hasil observasi awal, wawancara secara langsung di SMP Negeri 117 Jakarta, guru menyatakan masih menggunakan model pembelajaran konvensional yaitu model pembelajaran langsung, dan dari hasil penyebaran angket yang telah dilakukan pada beberapa siswa kelas VII SMP Negeri 117 Jakarta yang tediri dari 50 siswa, $44 \%$ siswa merasa malas ketika mendengar penjelasan yang didominasi oleh guru, $74 \%$ siswa lebih memilih belajar secara berkelompok dibandingkan belajar secara individu dan $62 \%$ siswa lebih memilih bertanya kepada teman dibandingkan kepada guru ketika belum memamami materi. Berdasarkan hasil tersebut dapat disimpulkan bahwa model Pembelajaran konvensional yang biasanya diterapkan oleh guru kurang memberi pengaruh yang lebih baik di dalam proses pembelajaran, karena tidak sesuai dengan karakteristik yang diinginkan siswa, maka dari itu guru harus mampu memilih model pembelajaran yang tepat untuk diterapkan pada saat proses pembelajaran berlangsung. Salah satu alternatif untuk memecahkan permasalahan pada proses pembelajaran Bahasa Indonesia tersebut adalah dengan menerapkan model pembelajaran yang memiliki karakteristik sesuai dengan keinginan siswa. Model pembelajaran merupakan pola tertentu yang dapat menolong guru dalam mendesain pembelajaran sehingga siswa terbantu dan tujuan pembelajaran dapat tercapai. Model pembelajaran yang dapat diterapkan sangat banyak jenis dan variasinya, model pembelajaran memilki karakteristik serta kelebihan dan kekurangannya masing-masing, dan diatara banyak jenis model pembelajaran tersebut peneliti memilih untuk menerapkan model pembelajaran Think Pair Share (TPS). (Trianto: 2011). 
Hal inilah yang membuat peneliti tertarik untuk melakukan penelitian yang berjudul "Upaya Meningkatkan Hasil Belajar Bahasa Indonesia pada Kompetensi Membaca dengan Model Think Pair and Share Siswa Kelas VII-7 di SMP Negeri 117 Jakarta”.

\section{METODE PENELITIAN}

Penelitian tindakan kelas ini dilaksanakan di SMP Negeri 117 yang beralamat di Jalan Taruna Pahlawan Revolusi, Pondok Bambu Duren Sawit. Jakarta Timur. 13430. Waktu penelitian akan dilaksanakan pada semester ganjil tahun pelajaran 2020/2021 mulai bulan Oktober sampai bulan Desember. Penelitian adalah penelitian tindakan kelas. Penelitian tindakan kelas merupakan suatu pencermatan terhadap kegiatan belajar berupa sebuah tindakan,yang sengaja dimunculkan terjadi dalam sebuah kelas secara bersama. Pusat (2004). Tindakan tersebut diberikan oleh guru selama dua siklus dengan bagan sebagai berikut :

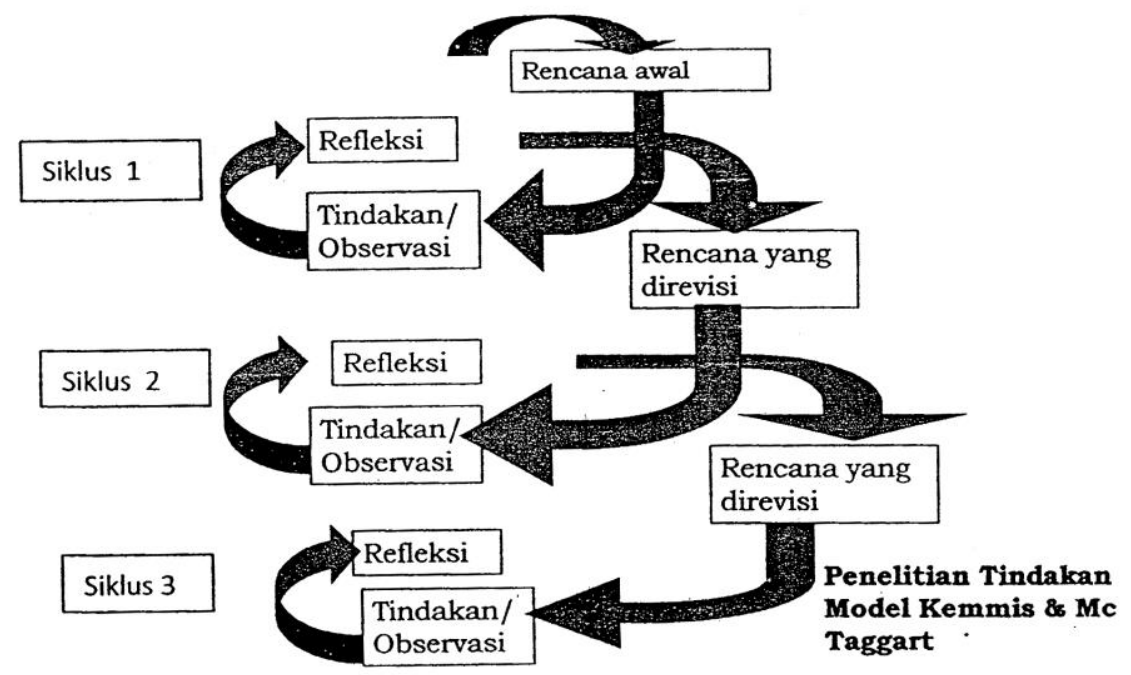

Gambar 1. Desain Penelitian Tindakan Kelas

Metode penelitian yang digunakan dalam penelitian ini adalah Metode Penelitian Tindakan Kelas (PTK). Menurut Arikunto dkk (2006;74) Penelitian Tindakan Kelas adalah penelitian tindakan untuk memperbaiki mutu praktik pembelajaran di kelasnya,sehingga berfokus pada proses pembelajaran yang terjadi di kelas. Penelitian tindakan kelas adalah tindakan yang nyata yang diyakini lebih baik dilakukan. Penelitian ini dilakukan dengan siklus I dan siklus II.

Instrumen adalah alat untuk memperoleh data penelitian. Instrumenyang digunakan dalam penelitian ini adalah: (1) Soal (2) Lembar pengamatan (3) lembar kerja siswa (4) Catatan lapangan. Data yang dikumpulkan dianalisis dan ditafsirkan berdasarkan kajian pustaka serta pengalaman guru. Sedangkan hasil belajar siswa dianalisis berdasarkan ketuntasan belajar dan daya serap siswa.

\section{HASIL DAN PEMBAHASAN}

Kondisi awal kemampuan siswa pada hasil belajar bahasa Indonesia adalah sebagai berikut :daya serap 60,14. Kondisi seperti ini dimungkinkan karena metode pembelajaran yang kurang tepat, kurangnya motivasi siswa belajar bahasa Indonesia, dan kurangnya siswa terlibat dalam proses belajar karena pembelajaran lebih terpusat pada guru. 
Tabel 1. Hasil Tes Pra Siklus

\begin{tabular}{ccc}
\hline NO. & INTERVAL NILAI & JUMLAH SISWA \\
\hline 1 & $0-19$ & 0 \\
\hline 2 & $20-39$ & 0 \\
\hline 3 & & 14 \\
\hline 4 & $30-59$ & 19 \\
\hline 5 & $80-100$ & 2 \\
\hline & Daya Serap & $\mathbf{6 0 , 1 4 \%}$ \\
\hline
\end{tabular}

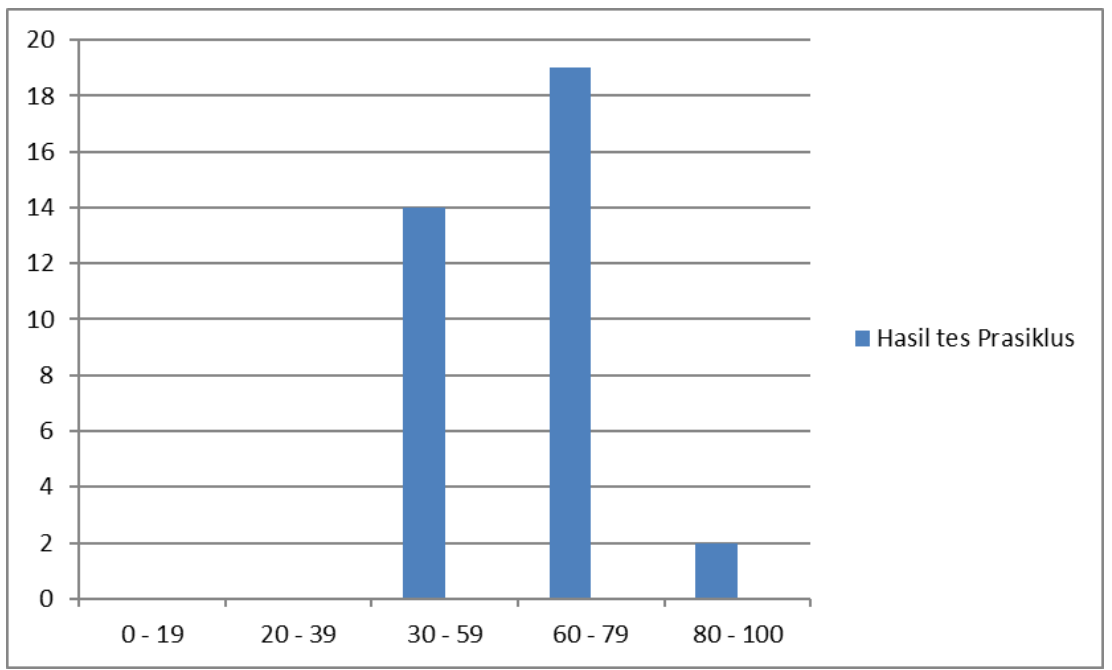

Gambar 2. Grafik Hasil Tes Pra Siklus

Siklus I

Setelah mengikuti kegiatan belajar mengajar dengan menggunakan model think pair and share, siswa diberi tes pilihan ganda 10 soal dan esai 5 soal, maka diperoleh hasil sebagai berikut:

Tabel 2. Hasil Belajar Siklus I

\begin{tabular}{clc}
\hline NO & \multicolumn{1}{c}{ KETERANGAN } & NIL \\
\hline 1. & Nilai Tertinggi & 90 \\
\hline 2. & Nilai Terendah & 50 \\
\hline 3. & Nilai diatas KKM & 25 \\
\hline 4. & Nilai dibawah KKM & 9 \\
\hline 5. & Nilai Rata - Rata & 74.85 \\
\hline 6. & Ketuntasan Belajar (dalam \%) & 73.52 \\
\hline
\end{tabular}




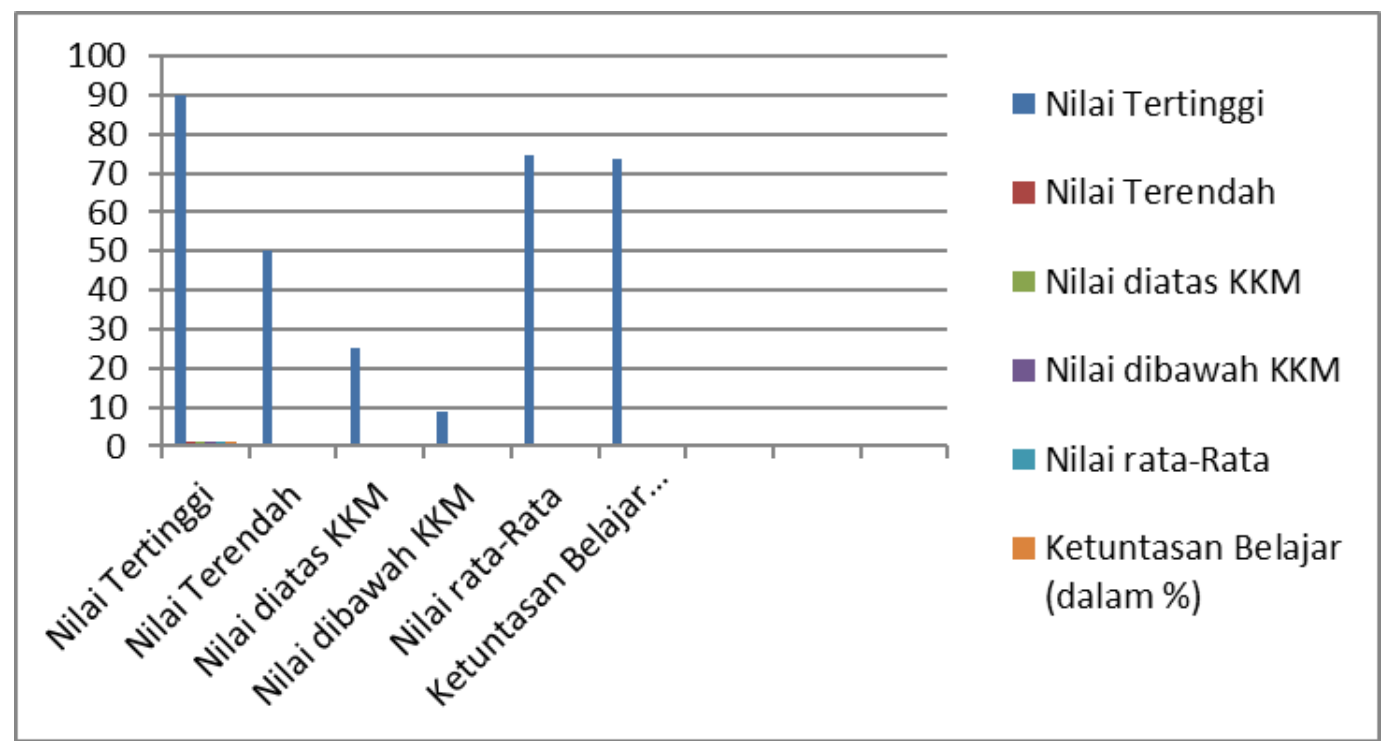

Gambar 3. Grafik Hasil Tes Siklus 1

Berdasarkan data di atas bahwa nilai rata-rata tes siklus 1 sudah bagus akan tetapi masih ada 9 siswa yang mendapat nilai di bawah 71 atau di bawah KKM.

Hasil pengamatan aktivitas siswa yang dilakukan pada siklus 1 menunjukkan bahwa siswa belum dapat berpartisipasi dengan baik karena dari data terlihat baru mencapai $64,74 \%$ dari indikator keberhasilan $75 \%$, perhatian mereka terhadap pembelajaran mencapai $73,52 \%$,sedangkan kerjasama mencapai $76,47 \%$ dari indikator keberhasilan $75 \%$,seperti tampak pada tabel.

Tabel 4. Rekapitulasi persentase keaktifan siswa pada kegiatan belajar mengajar siklus 1

\begin{tabular}{clc}
\hline NO & ASPEK YANG DINILAI & PERSENTASE KEAKTIFAN \\
\hline 1. & Partisipasi & 64,74 \\
\hline 2. & Perhatian & 73,52 \\
\hline 3. & Kerjasama & 76,47 \\
\hline 4. & Rata - Rata & 72,54 \\
\hline
\end{tabular}

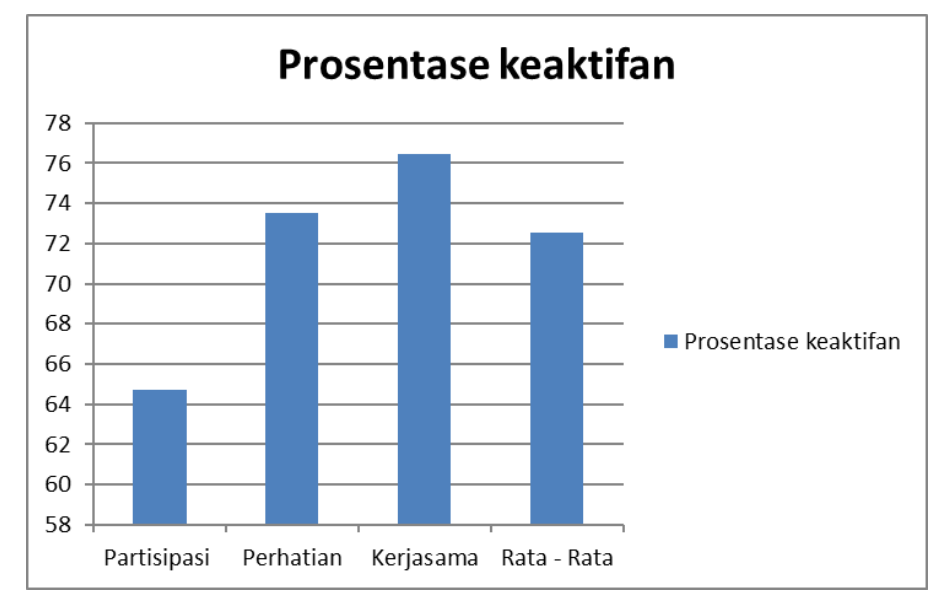

Gambar 4. Grafik Rekapitulsi Keaktifan Siswa

Pada kegiatan siklus I yang harus diperbaiki pada siklus II adalah sebagai berikut: (1) Siswa yang takut bertanya diberi kesempatan untuk bertanya lebih dulu dengan diberi motivasi oleh guru. (2) Siswa yang pasif, individual, serta kurang perhatian hendaknya didekati dan diberi motivasi lebih oleh peneliti. (3) Untuk 9 siswa dengan nilai KKM di bawah 71 diberi remedial.

\section{Siklus II}


Setelah mengikuti proses pembelajaran dengan model think pair dan share, siswa diberi tes pilihan ganda sebanyak 10 soal dan diperoleh hasil sebagai berikut :

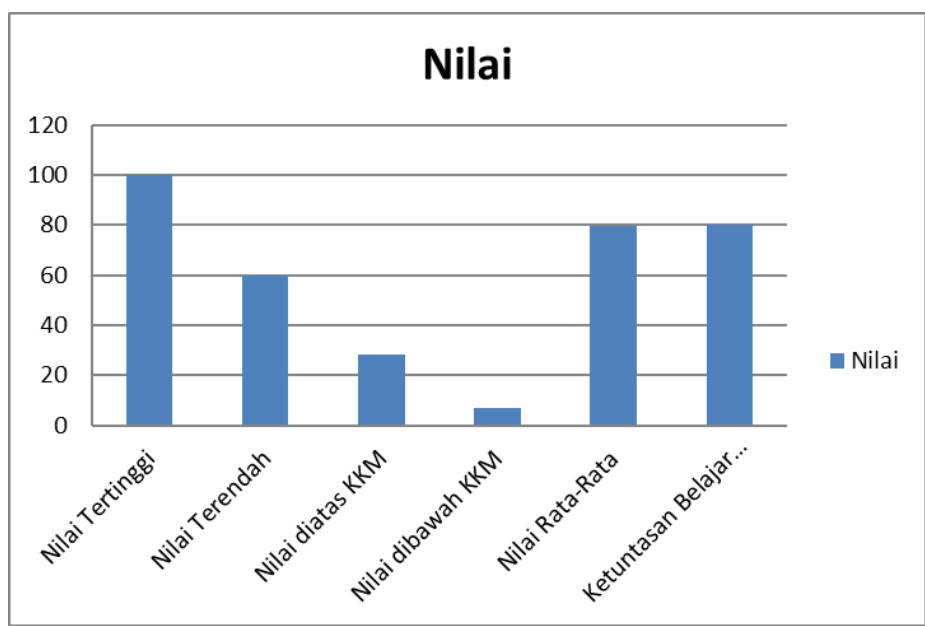

Gambar 5. Grafik Hasil tes Siklus II

Berdasarkan data-data di atas menunjukkan adanya peningkatan hasil belajar terlihat dari nilai rata-rata dan ketuntasan belajar. Meskipun masih ada lima orang siswa yang nilainya di bawah KKM.

Hasil pengamatan aktivitas siswa yang dilakukan pada siklus II terlihat bahwa aktivitas siswa jauh meningkat, siswa lebih bersemangat untuk saling memberi pendapat, berkomentar, berpartisipasi untuk memberi penilaian atas penampilan teman yang tampil. Persentasi partisipasi mencapai $82,85 \%$, perhatian $80 \%$, dan kerja sama $77,14 \%$ dari indikator kebehasillan $75 \%$. Peningkatan aktivitas siswa dapat terlihat pada tabel dan grafik berikut:

Tabel 6. Rekapitulasi persentase keaktifan siswa pada kegiatan belajar mengajar siklus II

\begin{tabular}{clc}
\hline NO & ASPEK YANG DINILAI & PERSENTASE KEAKTIFAN \\
\hline 1. & & 82,85 \\
\hline 2. & Perhatian & 80,00 \\
\hline 3. & Kerjasama & 77,14 \\
\hline 4. & Rata - Rata & 79,98 \\
\hline
\end{tabular}

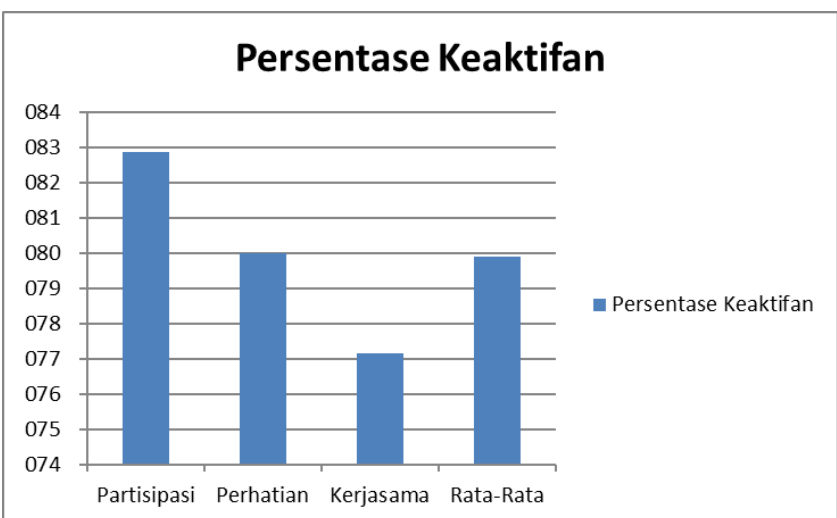

Gambar 6. Grafik Rekapitulasi Keaktifan Siswa Siklus II 


\section{Analisis Perbandingan Hasil Belajar dan Keaktifan Siswa pada Siklus I dan Siklus II}

Tabel 7. Perolehan Nilai Rata-rata

\begin{tabular}{|c|l|c|c|c|}
\hline No. & \multicolumn{1}{|c|}{ KETERANGAN } & Pra Siklus & Siklus 1 & Siklus 2 \\
\hline 1. & Nilai Tertinggi & 80 & 90 & 100 \\
\hline 2. & Nilai Terendah & 40 & 50 & 60 \\
\hline 3. & Nilai diatas KKM & 6 & 25 & 28 \\
\hline 4. & Nilai dibawah KKM & 29 & 9 & 7 \\
\hline 5. & Nilai Rata - Rata & 60,14 & 74,85 & 79,71 \\
\hline 6. & $\begin{array}{l}\text { Ketuntasan Belajar } \\
\text { (dalam \%) }\end{array}$ & 17,14 & 73,52 & 80,00 \\
\hline
\end{tabular}

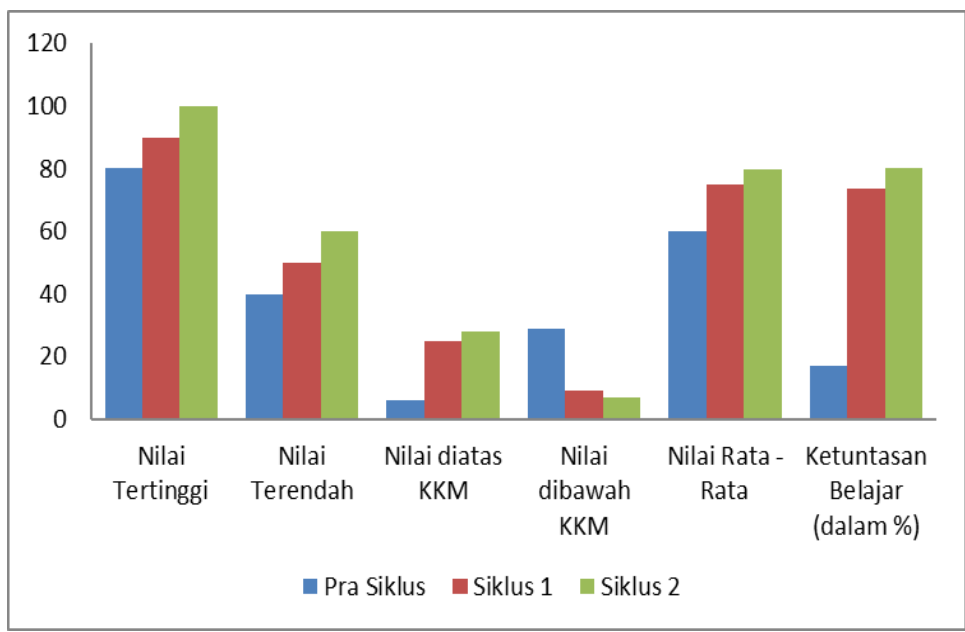

Gambar 7. Grafik Peningkatan Nilai Rata-rata

Perbandingan hasil belajar siswa pada siklus I dengan siklus II adalah sebagai berikut : nilai ratarata pada siklus II adalah 79,71menunjukkan peningkatan 4,86 jika dibandingkan dengan siklus I yang memiliki nilai rata-rata hasil belajar 74,85. Demikian juga dengan ketuntasan belajar menunjukkan peningkatan pada siklus I 73,52 \% menjadi $80,00 \%$ pada siklus II. Ini berarti menunjukkan model pembelajaran think pair and share dapat meningkatkan hasil belajar bahasa Indonesia.

Tabel 8. Persentase Peningkatan Aktivitas Siswa pada Siklus I dan Siklus II

\begin{tabular}{clll}
\hline No. & ASPEK YANG DINILAI & Siklus 1 & Siklus 2 \\
\hline 1. & Partisipasi & 64,74 & 82,25 \\
\hline 2. & Perhatian & 73,52 & 80,00 \\
\hline 3. & Kerjasama & 76,47 & 77,14 \\
\hline 4. & Rata - Rata & 72,54 & 79,98 \\
\hline
\end{tabular}




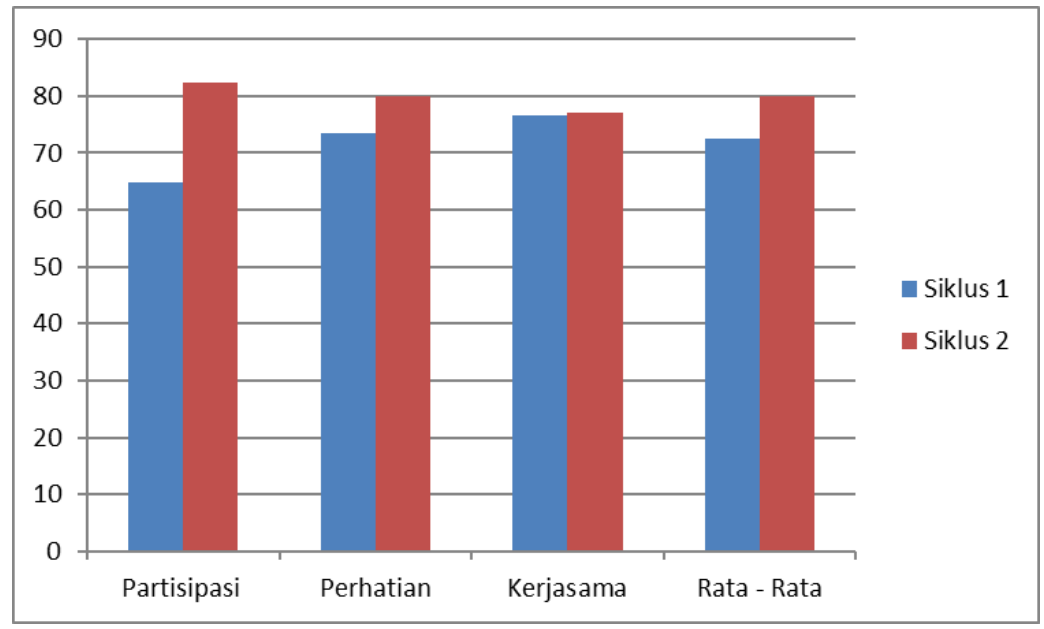

Gambar 8. Prosentase Peningkatan Aktivitas Siswa

Berdasarkan tabel di atas terlihat perbandingan aktivitas belajar siswa pada siklus I dan siklus II adalah sebagai berikut : nilai rata-rata aktivitas siswa pada siklus I 72,54\% dan nilai rata-rata aktivitas siswa pada siklus II adalah 79,98 \%, sehingga tampak ada peningkatan aktivitas siswa sebesar 7,44 \% dari siklus I ke siklus II. Ini menandakan bahwa model pembelajaran think pair and share dapat meningkatkan aktivitas belajar siswa pada mata pelajaran bahasa Indonesia. Hasil di tersebut selaras dengan penelitian yang dilakukan oleh Zulkarnain, dkk (2015) bahwa penerapan model pembelajaran Think Pair and share memiliki mampu meningkatkan pemahaman siswa terhadap logika matematis di tingkat SMP.

\section{KESIMPULAN}

\section{Simpulan}

Berdasarkan pembahasan pada bab IV, diperoleh data sebagai berikut : pada siklus I hasil belajar rata-rata nilai 74,85 menjadi 79,71 pada siklus II sehingga terjadi peningkatan rata-rata nilai 4,86. Demikian juga dengan aktivitas belajar siswa pada siklus I 72,54\% menjadi 79,98 \% pada siklus II, sehingga terjadi peningkatan 7,44\%. Oleh karena itu,dapat disimpulkan bahwa penggunaan model pembelajaran think pair and share dapat meningkatkan hasil belajar bahasa Indonesia pada kompetensi membaca siswa kelas VII-7 di SMP Negeri 117 DKI Jakarta.

Saran

Berdasarkan hasil penelitian ini, peneliti menyarankan sebagai berikut: (1) Bagi guru bahasa Indonesia disarankan untuk menggunakan model pembelajaran think pair and share untuk meningkatkan hasil belajar siswa khususnya untuk kompetensi membaca. (2) Guru hendaknya senantiasa menggunakan metode dan model pembelajaran yang bervariasi agar kegiatan belajar mengajar menjadi lebih menarik, sehingga pelajaran bahasa Indonesia tidak membosankan dan menjenuhkan. (3) Dalam kegiatan belajar mengajar komunikasi aktif dengan siswa perlu ditingkatkan agar siswa menjad lebih termotivasi dan berminat terhadap pelajaran bahasa Indonesia. (4) Penelitian tindakan kelas perlu terus dilakukan oleh guru. agar dapat memahami permasalahan dan kondisi yang ada pada siswa dan dapat mencari pemecahannya. (5) Sekolah hendaknya dapat menyediakan fasilitas yang memadai sesuai dengan kebutuhan pembelajaran sehingga guru juga dapat meningkatkan kualitas pembelajaran.

\section{DAFTAR PUSTAKA}

Arikunto, Suharsimi. (2006). Penelitian Tindakan Kelas. Jakarta: Bumi Aksara Dimyati dan Mudjiono. (2013). Belajar dan Pembelajaran. Jakarta: Rineka Cipta Djamarah, dkk. (2006). Strategi Belajar Mengajar edisi revisi. Jakarta: Rineka. Kunandar. (2013). Penilaian Autentik. Jakarta: PT. Raja Grafindo Persada. 
Lie, Anita. (2005). Cooperatif Learning. Jakarta: Gramedia.

Mulyatiningsih, E. (2011). Metode Penelitian Terapan Bidang Pendidikan. Yogyakarta: Alfabeta.

Priyatni, E.T. (2014). Desain Pembelajaran Bahasa Indonesia dalam Kurikulum 2013. Jakarta: Bumi Aksara

Rusman. (2015). Model-Model Pembelajaran. Jakarta: Rajagrafindo Persada.

Sadikin, Asep Ganda dkk. (2004). Kompetensi Berbahasa Indonesia untuk SMP Kelas VII. Jakarta:Grafindo Media Pratama.

Sanjaya, Wina. (2011). Strategi Pembelajaran Berorientasi Standar Proses Pendidkan. Jakarta: CV. Kencana.

Sirajuddin, Nurasia \& Hafiludin Samparadja. (2015). Meningkatkan Hasil Belajar Matematika Melalui Model Pembelajaran Kooperatif Tipe Think-PairShare (TPS) Siswa Kelas VII E SMP Negeri 7 Kediri. Penelitian Pendidikan Matematika, (Online), Vol. 3, No. 3.

Suprijono, Agus. (2011). Cooperative Learning; Teori dan Aplikasi PAIKEM. Yogyakarta: Pustaka Belajar.

Tarigan, Henry Guntur. (1994). Membaca sebagai Suatu Keterampilan Berbahasa. Bandung : IKIP

Trianto. (2011). Model-Model Pembelajaran Inovatif Berorientasi Konstruktivitis. Jakarta: Prestasi Pustaka.

Yuniastuti, E. (2013). Peningkatan keterampilan proses, motivasi, dan hasil belajar biologi dengan strategi pembelajaran inkuiri terbimbing pada siswa kelas VII SMP Kartika V1 Balikpapan. Jurnal penelitian pendidikan, 13(1).

Zulkarnain, I., \& Djamilah, S. (2015). Penerapan Model Pembelajaran Think Pair and Share Terhadap Kemampuan Pemahaman Matematis Siswa Sekolah Menengah Pertama. EDU-MAT: Jurnal Pendidikan Bahasa Indonesia, 3(1). 